\title{
Solusi Model Perubahan Garis Pantai dengan Metode Transformasi Elzaki
}

\author{
Maya Sari Wahyuni ${ }^{1, \text { a) }}$, Sukarna ${ }^{1, b)}$, dan Muh. Irham Rosadi $\mathrm{L}^{1, \mathrm{c})}$ \\ ${ }^{1}$ Jurusan Matematika FMIPA Universitas Negeri Makassar, 90224 \\ a) mayasari.wahyuni@gmail.com \\ b) sukarna@unm.ac.id \\ c) irhamrosadi40@gmail.com
}

\begin{abstract}
Abstrak. Pantai merupakan kawasan yang sering dimanfaatkan untuk berbagai kegiatan manusia, namun seringkali upaya pemanfaatan tersebut menyebabkan permasalahan pantai sehingga garis pantai berubah. Salah satu cara yang dapat digunakan untuk mengetahui perubahan garis pantai yaitu dengan membuat model matematika. Model perubahan garis pantai berbentuk persamaan diferensial parsial dapat diselesaikan secara analitik dengan menggunakan metode transformasi Elazki. Metode transformasi Elzaki merupakan salah satu bentuk transformasi integral yang diperoleh dari integral Fourier sehingga didapatkan transformasi Elzaki dan sifat-sifat dasarnya. Perubahan garis pantai pada penelitian ini dipengaruhi oleh adanya groin. Penyelesaian model perubahan garis pantai dengan metode transformasi Elzaki dilakukan dengan menerapkan transformasi Elzaki pada model perubahan garis pantai untuk memperoleh model perubahan garis pantai yang baru, kemudian menerapkan syarat batas, kemudian menerapkan invers transformasi Elzaki sehingga diperoleh solusi model perubahan garis pantai. Berdasarkan hasil penelitian, diperoleh bahwa terdapat kesamaan antara pola grafik yang dihasilkan dari solusi model perubahan garis pantai dengan metode transformasi Elzaki dan solusi model perubahan garis pantai dengan metode numerik.
\end{abstract}

Kata Kunci: Perubahan garis pantai, Groin, Analitik, Transformasi Elzaki.

\begin{abstract}
The beach is a region that is often used for various human activities, however often these utilization efforts cause beach problems so that the shoreline changes. One way that can be used to determine changes in shoreline is to make a mathematical model. The shoreline change model shaped of partial differential equation can be solved analytically by using the Elzaki transform method. The Elzaki transform method is a form of integral transform obtained from the Fourier integral so that the Elzaki transform and its basic properties are obtained. Shoreline change in this research were affected by groyne. Solution of shoreline change model using Elzaki transform method is carried by applying the Elzaki transform to the shoreline change model to obtain a new shoreline change model, then applying the boundary value, then applying the inverse of Elzaki transform so obtained a solution shoreline change model. Based on the research result, it was found that there was a similiarity between the graphic patterns generated from the solution of shoreline change model using Elzaki transform method and the solution of shoreline change model using numerical method.
\end{abstract}

Keywords: Shoreline change, Groyne, Analitic, Elzaki transform 


\section{LATAR BELAKANG}

Pantai merupakan kawasan yang sering dimanfaatkan untuk berbagai kegiatan manusia, namun seringkali upaya pemanfaatan kawasan pantai tidak dilandasi oleh pemahaman yang baik akan perilaku pantai. Akibatnya, timbul berbagai permasalahan pantai seperti abrasi dan akresi. Untuk keperluan perencanaan pengelolaan kawasan pantai maka diperlukan penelitian tentang perubahan garis pantai. Salah satu cara yang dapat digunakan untuk mengetahui perubahan garis pantai yaitu dengan membuat model matematika.

Salah satu model matematika yang sangat penting adalah Persamaan Diferensial. Menurut Side (2014) persamaan diferensial merupakan persamaan yang melibatkan satu atau lebih variabel terikat terhadap satu atau lebih variabel bebas. Teknik penyelesaian persamaan diferensial dapat diselesaikan secara analitik dan numerik, terdapat beberapa contoh kasus persamaan diferensial yang tidak dapat diselesaikan dengan metode pemisahan variabel sehingga persamaan diferensial tersebut diselesaikan dengan metode numerik. Padahal jika dianalisis lebih dalam persamaan diferensial tersebut masih dapat diselesaikan secara analitik, yaitu dengan menggunakan metode transformasi integral.

Model perubahan garis pantai dibuat berdasarkan pada persamaan kontinuitas sedimen, yaitu sepanjang pantai dibagi menjadi sejumlah sel dengan panjang yang sama, pada setiap sel ditinjau angkutan sedimen yang masuk dan keluar. Triatmodjo (1999) memperoleh persamaan kontinuitas sedimen sebagai berikut $\frac{\partial y}{\partial t}=-\frac{1}{d} \frac{\partial Q}{\partial x}$. Persamaan kontinuitas sedimen ini terdiri atas dua variabel bebas $x$ dan $t$, serta dua variabel terikat $Q$ dan $y$ sehingga perlu dicari hubungan antara $Q$ dan $y$, berdasarkan penelitian yang dilakukan oleh (Dabees, 2000) diperoleh bahwa $\frac{\partial y}{\partial t}=\frac{2 Q_{0}}{d} \frac{\partial^{2} y}{\partial x^{2}}$, persamaan inilah yang merupakan persamaan untuk menghitung perubahan garis pantai. Pada penelitian ini perhitungan transpor sedimen pantai menggunakan persamaan USACE (2003):

$$
Q=Q_{0} \sin \left(2 \alpha_{b}\right)
$$

dimana

$$
Q_{0}=K_{r m s}\left(\frac{\rho \sqrt{g}}{16 \sqrt{\gamma_{b}}\left(\rho_{s}-\rho\right)(1-n)}\right) H_{b r m s}^{5 / 2}
$$

Metode transformasi Elzaki merupakan salah satu bentuk transformasi integral yang diperoleh dari integral Fourier sehingga didapatkan transformasi Elzaki dan sifat-sifat dasarnya, Metode ini pertama kali diperkenalkan oleh Tarig. M. Elzaki pada tahun 2011 dan efektif untuk menyelesaikan permasalahan pada PDB, PDP, sistem pada persamaan diferensial dan banyak diaplikasikan pada bidang teknik dan fisika seperti mesin, lintasan listrik, masalah balok, sistem linear dinamik, signals-delay pada persamaan diferensial dan persamaan statistik (Elzaki, Elzaki, \& Elnour, 2012)

Elzaki (2011) mendefinisikan bahwa, jika diberikan himpunan A dengan anggotanya adalah fungsi eksponensial berpangkat, sehingga A dapat ditulis,

$$
A=\left\{f(t): \exists M, k_{1} \text { dan } k_{2}>0:|f(t)|<\left\{\begin{array}{c}
M e^{\frac{|t|}{k_{1}}} j i k a t \in(-\infty, 0] \\
M e^{\frac{|t|}{k_{2}}} j i k a t \in[0, \infty)
\end{array}\right\}\right.
$$

dengan $M$ adalah bilangan berhingga dan $k_{1}, k_{2}$ adalah bilangan berhingga atau tak berhingga. maka transformasi Elzaki $f(t)$ adalah

$$
E[f(t)]=T(v)=v \int_{0}^{\infty} f(t) e^{\frac{-t}{v}} d t, \quad t \geq 0, \quad-k_{1}<v<k_{2}
$$


Invers transformasi Elzaki merupakan proses kebalikan dari transformasi Elzaki yang didefinisikan sebagai berikut: Misalkan $T(v)$ adalah suatu fungsi $f(t)$ dari transformsi Elzaki dengan kata $E[f(t)]=T(v)$ maka $f(t)$ disebut invers transformasi Elzaki dari $T(v)$. Hubungan ini dapat dilihat pada Tabel 1.

TABEL 1. Transformasi Elzaki dari Beberapa Fungsi (Minarti, Kiftiah, \& Helmi, 2015) (Elzaki, Elzaki, \& Elnour, 2012)

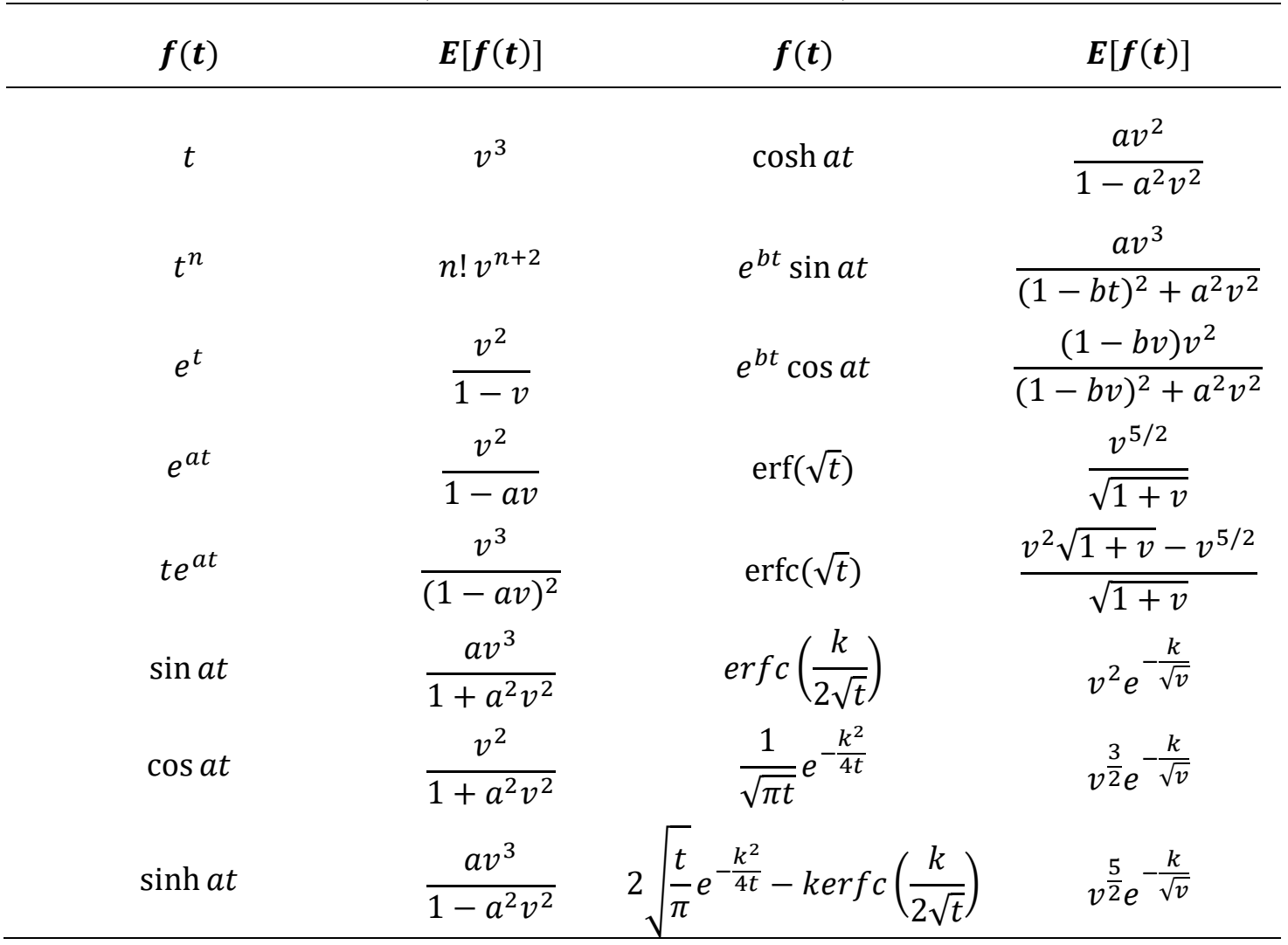

Penelitian tentang perubahan garis pantai telah banyak dilakukan secara numerik, salah satunya dengan menggunakan metode beda hingga. Sakka (2011) melakukan penelitian perubahan garis pantai di delta Sungai Jeneberang Makassar dengan memperhitungkan sedimen yang masuk dan keluar sel serta mempertimbangkan pengaruh tinggi dan sudut gelombang pecah dengan metode numerik beda hingga.

Selain secara secara numerik, penelitian tentang perubahan garis pantai juga dapat dilakukan secara analitik. Syarifah Meurah Yuni, Ichsan Setiawan, dan Okvita Maufiza (2014) melakukan penelitian untuk mencari solusi model perubahan garis pantai dengan menggunakan transformasi Laplace, pada penelitian ini diperoleh bahwa perubahan garis pantai dipengaruhi oleh besarnya abrasi dan akresi yang terjadi, arah datang gelombang, transpor sedimen, kedalaman air pada saat gelombang pecah, dan sudut datang gelombang pecah.

Penelitian ini dilakukan dengan cara mencari informasi yang berkaitan dengan penelitian yang dilakukan dengan cara mengumpulkan literatur-literatur dari berbagai sumber. Setelah model perubahan garis pantai diperoleh, dengan menggunakan transformasi Elzaki maka diperoleh model perubahan garis pantai yang baru. Kemudian menerapkan syarat batas untuk mendapatkan solusi khusus $\mathrm{Y}(v)$. Kemudian mentransformasikan nilai $\mathrm{Y}(v)$ yang diperoleh dengan invers transformasi Elzaki sehingga diperoleh solusi eksak atau solusi khusus dalam bentuk $\mathrm{y}(x, t)$. Kemudian melakukan simulasi menggunakan aplikasi Matlab R2015. 


\section{HASIL PENELITIAN}

\section{Solusi Model Perubahan Garis Pantai}

Penelitian ini menyelesaikan model perubahan garis pantai yang dipengaruhi oleh adanya groin secara analitik yaitu dengan menggunakan transformasi Elzaki, dengan syarat batas yang digunakan adalah:

$$
\begin{gathered}
y(x, 0)=0 \\
\frac{\partial y}{\partial x}(w, t)=\tan a_{b} \\
\lim _{x \rightarrow \infty} y(x, t)=0 \\
\lim _{x \rightarrow-\infty} y(x, t)=0
\end{gathered}
$$

Dengan asumsi bahwa mula-mula garis pantai lurus maka diambil nilai awal $y(x, 0)=0$ yang menyatakan bahwa pada saat $t=0$ pantai tidak mengalami perubahan garis pantai artinya garis pantai lurus sepanjang $x$. Sedangkan syarat batas $\frac{\partial y}{\partial x}(w, t)=\tan a_{b}$ menyatakan bahwa perubahan garis pantai di setiap sel $x$ dipengaruhi oleh besarnya sudut datang gelombang pecah ke pantai di mana groin berada pada titik $x=w$, syarat batas $\lim \lim _{x \rightarrow \infty} y(x, t)=0$ dan $\lim _{x \rightarrow-\infty} y(x, t)=0$ menyatakan bahwa semakin jauh dari groin maka perubahan garis pantai yang ditimbulkan semakin kecil atau bahkan tidak mengalami perubahan karena sudah tidak mendapat pengaruh dari groin.

Dalam menentukan solusi dari Persamaan model perubahan garis pantai $\frac{\partial y}{\partial t}=\frac{2 Q_{0}}{d} \frac{\partial^{2} y}{\partial x^{2}}$ digunakan langkah-langkah berikut:

\section{Menerapkan transformasi Elzaki pada model perubahan garis pantai}

Untuk transformasi Elzaki pada ruas kiri diperoleh

$$
\begin{gathered}
E\left[\frac{\partial y}{\partial t}\right]=v \int_{0}^{\infty} \frac{\partial y}{\partial t} e^{\frac{-t}{v}} d t \\
E\left[\frac{\partial y}{\partial t}\right]=\left.v y(x, \mathrm{t}) e^{\frac{-t}{v}}\right|_{0} ^{\infty}+\int_{0}^{\infty} y(x, \mathrm{t}) e^{\frac{-t}{v}} d t \\
E\left[\frac{\partial y}{\partial t}\right]=v(0-y(x, 0))+\frac{Y(v)}{v} \\
E\left[\frac{\partial y}{\partial t}\right]=\frac{Y(v)}{v}-v y(x, 0)
\end{gathered}
$$

untuk transformasi Elzaki pada ruas kanan diperoleh dengan menggunakan aturan Leibnitz, maka

$$
\begin{gathered}
E\left[\frac{2 Q_{0}}{d} \frac{\partial^{2} y}{\partial x^{2}}\right]=\frac{2 Q_{0}}{d} v \int_{0}^{\infty} \frac{\partial^{2} y}{\partial x^{2}} e^{-\frac{t}{v}} d t \\
E\left[\frac{2 Q_{0}}{d} \frac{\partial^{2} y}{\partial x^{2}}\right]=\frac{2 Q_{0}}{d} \frac{\partial^{2}}{\partial x^{2}}\left(v \int_{0}^{\infty} y(t) e^{-\frac{t}{v}} d t\right) \\
E\left[\frac{2 Q_{0}}{d} \frac{\partial^{2} y}{\partial x^{2}}\right]=\frac{2 Q_{0}}{d} \frac{\partial^{2} Y(v)}{\partial x^{2}}
\end{gathered}
$$


sehinngga diperoleh

$$
\begin{gathered}
E\left[\frac{\partial y}{\partial t}\right]=E\left[\frac{2 Q_{0}}{d} \frac{\partial^{2} y}{\partial x^{2}}\right] \\
\frac{Y(v)}{v}-v y(x, 0)=\frac{2 Q_{0}}{d} \frac{\partial^{2} Y(v)}{\partial x^{2}} \\
Y(v)-v^{2} y(x, 0)=\frac{2 Q_{0} v}{d} \frac{\partial^{2} Y(v)}{\partial x^{2}}
\end{gathered}
$$

\section{Menerapkan syarat batas}

Dengan menyubstitusikan $y(x, 0)=0$ ke Persamaan (1) diperoleh:

$$
Y(v)-\frac{2 Q_{0} v}{d} \frac{\partial^{2} Y(v)}{\partial x^{2}}=0
$$

Persamaan (2) hanya mengandung turunan terhadap variabel bebas $x$, sehingga dapat dipandang sebagai persamaan diferensial biasa, untuk mendapatkan solusi dari Persamaan (2) menggunakan metode persamaan karakteristik. Persamaan karakteristik dari Persamaan (2) adalah $\lambda_{1.2}=$ $\pm \sqrt{\frac{d}{2 Q_{0} v}}$, dengan demikian solusi umum dari Persamaan (2) adalah:

$$
Y(v)=c_{1} e^{\sqrt{\frac{d}{2 Q_{0} v}} x}+c_{2} e^{-\sqrt{\frac{d}{2 Q_{0} v}} x}
$$

Untuk syarat batas $\frac{\partial y}{\partial x}(w, t)=\tan a_{b}$ dengan menerapkan transformasi Elzaki didapat:

$$
\begin{gathered}
E\left[\frac{\partial y}{\partial x}(w, t)\right]=E\left[\tan a_{b}\right] \\
\frac{\partial Y}{\partial x}(w, v)=v^{2} \tan a_{b}
\end{gathered}
$$

Untuk syarat batas $\lim _{x \rightarrow \infty} y(x, t)=0$ dengan menerapkan transformasi Elzaki didapat:

$$
\begin{gathered}
E\left[\lim _{x \rightarrow \infty} y(x, t)\right]=E[0] \\
\lim _{x \rightarrow \infty} Y(x, v)=0
\end{gathered}
$$

Untuk syarat batas $\lim _{x \rightarrow-\infty} y(x, t)=0$ dengan menerapkan transformasi Elzaki didapat:

$$
\begin{gathered}
E\left[\lim _{x \rightarrow-\infty} y(x, t)\right]=E[0] \\
\lim _{x \rightarrow-\infty} Y(x, v)=0
\end{gathered}
$$

Untuk mendapatkan solusi dari persamaan (3) ini dibagi menjadi dua yaitu dilakukan untuk mencari solusi di sebelah hulu groin dan sebelah hilir groin. Sebelah hulu groin adalah adalah daerah yang dimulai dari titik awal garis pantai yang akan diteliti sampai titik dimana groin berada, sedangkan sebelah hilir groin adalah daerah yang dimulai dari groin sampai titik akhir garis pantai yang akan diteliti. Untuk memperoleh solusi di sebelah hulu groin mula mula dengan menyubstitusikan Persamaan (3) ke Persamaan (5) sehingga diperoleh:

$$
\begin{gathered}
\lim _{x \rightarrow-\infty} Y(x, v)=0 \\
\lim _{x \rightarrow-\infty}\left(c_{1} e^{\sqrt{\frac{d}{2 Q_{0} v}} x}+c_{2} e^{-\sqrt{\frac{d}{2 Q_{0} v}} x}=0\right. \\
c_{1} \lim _{x \rightarrow-\infty} e^{\sqrt{\frac{d}{2 Q_{0} v}} x}+c_{2} \lim _{x \rightarrow-\infty} e^{-\sqrt{\frac{d}{2 Q_{0} v}} x}=0
\end{gathered}
$$


karena $c_{1} \lim _{x \rightarrow-\infty} e^{\sqrt{\frac{d}{2 Q_{0} v}} x}=0$, maka:

$$
c_{2} \lim _{x \rightarrow-\infty} e^{-\sqrt{\frac{d}{2 Q_{0} v}} x}=0
$$

karena $\lim _{x \rightarrow-\infty} e^{-\sqrt{\frac{d}{2 Q_{0} v}} x} \neq 0$, maka haruslah $c_{2}=0$

Substitusikan nilai $c_{2}=0$ ke turunan pertama Persamaan (3) terhadap $x$ untuk mendapatkan nilai $c_{1}$.

$$
\begin{gathered}
\frac{\partial Y}{\partial x}(x, v)=c_{1} \sqrt{\frac{d}{2 Q_{0} v}} e^{\sqrt{\frac{d}{2 Q_{0} v}} x}-c_{2} \sqrt{\frac{d}{2 Q_{0} v}} e^{-\sqrt{\frac{d}{2 Q_{0} v}} x} \\
\frac{\partial Y}{\partial x}(x, v)=c_{1} \sqrt{\frac{d}{2 Q_{0} v}} e^{\sqrt{\frac{d}{2 Q_{0} v}} x}
\end{gathered}
$$

berdasarkan Persamaan (4) maka:

$$
\begin{gathered}
\frac{\partial Y}{\partial x}(w, v)=c_{1} \sqrt{\frac{d}{2 Q_{0} v}} e^{\sqrt{\frac{d}{2 Q_{0} v} w}} \\
v^{2} \tan a_{b}=c_{1} \sqrt{\frac{d}{2 Q_{0} v}} e^{w \sqrt{\frac{d}{2 Q_{0} v}}} \\
c_{1}=\frac{2 Q_{0} v^{3} \sqrt{\frac{d}{2 Q_{0} v}} \tan a_{b}}{d} e^{-w \sqrt{\frac{d}{2 Q_{0} v}}}
\end{gathered}
$$

sehingga solusi khusus dari Persamaan (3) disebelah hulu groin adalah:

$$
\begin{gathered}
Y(v)=c_{1} e^{\sqrt{\frac{d}{2 Q_{0} v}} x}+c_{2} e^{-\sqrt{\frac{d}{2 Q_{0} v}} x} \\
Y(v)=\left(\frac{2 Q_{0} v^{3} \sqrt{\frac{d}{2 Q_{0} v}} \tan a_{b}}{d} e^{-w \sqrt{\frac{d}{2 Q_{0} v}}}\right) e^{\sqrt{\frac{d}{2 Q_{0} v}} x}+(0) e^{-\sqrt{\frac{d}{2 Q_{0} v}} x} \\
Y(v)=\sqrt{\frac{2 Q_{0}}{d}} \tan \left(a_{b}\right) v^{5 / 2} e^{-(w-x) \frac{\sqrt{\frac{d}{\sqrt{Q_{0}}}}}{\sqrt{v}}}
\end{gathered}
$$

Dengan cara yang sama, diperoleh solusi di sebelah hilir groin:

$$
Y(v)=-\sqrt{\frac{2 Q_{0}}{d}} \tan \left(a_{b}\right) v^{5 / 2} e^{-(x-w) \frac{\sqrt{\frac{d}{2 Q_{0}}}}{\sqrt{v}}}
$$

Berdasarkan Persamaan (7) dan Persamaan (8) diperoleh:

$$
Y(v)= \begin{cases}\sqrt{\frac{2 Q_{0}}{d}} \tan \left(a_{b}\right) v^{\frac{5}{2}} e^{-(w-x) \frac{\sqrt{\frac{d}{2 Q_{0}}}}{\sqrt{v}}} \quad \text { jika }-\infty<x \leq w \\ -\sqrt{\frac{2 Q_{0}}{d}} \tan \left(a_{b}\right) v^{\frac{5}{2}} e^{-(x-w) \frac{\sqrt{\frac{d}{2 Q_{0}}}}{\sqrt{v}}} & \text { jika } w \leq x<\infty\end{cases}
$$




\section{Mentransformasikan $Y(v)$ dengan invers transformasi Elzaki}

Langkah selanjutnya untuk memperoleh $y(x, t)$ adalah menerapkan invers transformasi Elzaki pada persamaan (9). Dengan menggunakan tabel transformasi Elzaki, invers transformasi Elzaki bagi persamaan (9) adalah:

$y(x, t)=\left\{\begin{array}{l}\sqrt{\frac{2 Q_{0}}{d}} \tan \left(a_{b}\right)\left(2 \sqrt{\frac{t}{\pi}} e^{-\frac{d}{8 Q_{0} t}(w-x)^{2}}-\sqrt{\frac{d}{2 Q_{0}}}(w-x) \operatorname{erfc}\left(\frac{\sqrt{\frac{d}{2 Q_{0} t}}(w-x)}{2}\right)\right),-\infty<x \leq w \\ -\sqrt{\frac{2 Q_{0}}{d}} \tan \left(a_{b}\right)\left(2 \sqrt{\frac{t}{\pi}} e^{-\frac{d}{8 Q_{0} t}(x-w)^{2}}-\sqrt{\frac{d}{2 Q_{0}}}(x-w) \operatorname{erfc}\left(\frac{\sqrt{\frac{d}{2 Q_{0}}}(x-w)}{2}\right)\right), w \leq x<\infty\end{array}\right.$

Persamaan (10) merupakan solusi bagi model perubahan garis pantai yang diperoleh dengan menggunakan transformasi Elzaki.

\section{Simulasi Solusi Model Perubahan Garis Pantai}

\section{Perbandingan dengan hasil solusi numerik}

Untuk menguji perbedaan dari solusi model perubahan garis pantai secara numerik dengan secara analitik digunakan uji $\mathrm{T}$ independent. Data yang digunakan adalah nilai dari garis pantai yang diperoleh dari solusi model perubahan garis pantai dengan metode numerik beda hingga (Triatmodjo, 1999) dan solusi model perubahan garis pantai dengan metode analitik transformasi Elzaki pada bulan pertama, kedua, ketiga, keempat, kesebelas, dan keduabelas pada setiap sel dari sel pertama hingga sel empat puluh.

TABEL 2. Uji T independent pada solusi model perubahan garis pantai secara numerik dengan analitik

\begin{tabular}{cccc}
\hline \multicolumn{2}{c}{ Rata-rata } & Selisih rata-rata & P-Value \\
Numerik & Analitik & 1,60079 & 0,512 \\
\hline 11,98175 & 10,38095 & \\
\hline
\end{tabular}

Pada uji T independent ini digunakan nilai signifikansi $\alpha=0,05$, berdasarkan Tabel 4.1 nilai $P$ Value yang diperoleh adalah 0,512. Dapat diambil kesimpulan bahwa nilai P-Value $=0,512$ lebih besar dari nilai signifikansi $\alpha=0,05$, sehingga tidak terdapat perbedaan yang secara signifikan dari solusi model perubahan garis pantai menggunakan metode numerik beda hingga dengan solusi model perubahan garis pantai menggunakan metode analitik transformasi Elzaki.

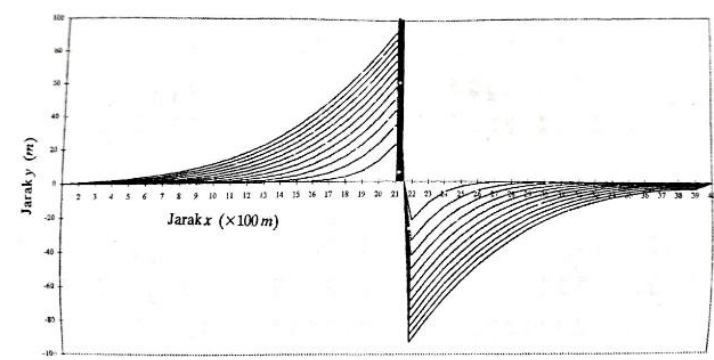

(a)

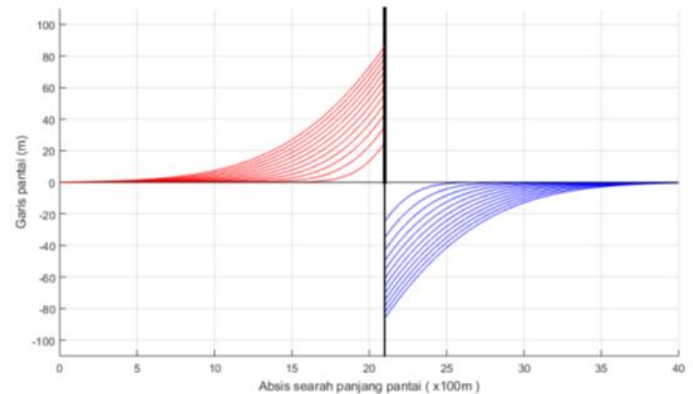

(b)

GAMBAR 1 Grafik perubahan garis pantai 
Gambar (1) diperoleh dengan memasukkan nilai $D=0,57 \mathrm{~mm}, \quad \rho=1030 \frac{\mathrm{kg}}{\mathrm{m}^{2}}$, $\rho_{s}=2650 \frac{\mathrm{kg}}{\mathrm{m}^{2}}, g=9,8 \times(24 \times 3600)^{2} \mathrm{~m} / \mathrm{hari}^{2}, \quad n=0,4, \quad C_{n}=5 \%, \quad H_{b}=1,5 \mathrm{~m}$, $d_{b}=2 m, a_{b}=8^{\circ}, x=0-4000 m, t=0-360$ hari dan $w=21$.

$\rho=1030 \frac{\mathrm{kg}}{\mathrm{m}^{2}}$ merupakan massa jenis air laut, $\rho_{s}=2650 \frac{\mathrm{kg}}{\mathrm{m}^{2}}$ merupakan massa jenis sedimen yang umumnya digunakan, $g=9,8 \times(24 \times 3600)^{2} \mathrm{~m} /$ hari $^{2}$ merupakan percepatan gravitasi dalam satuan $m /$ hari $^{2}, n=0,4$ merupakan nilai porositas pantai yang umumnya digunakan, $D=0,57 \mathrm{~mm}$ merupakan ukuran sedimen butiran sedimen pantai yang diperoleh di penelitian Sakka (2011), sedangkan $C_{n}=5 \%$ merupakan persentase kejadian gelombang pecah, $H_{b}=$ $1,5 \mathrm{~m}$ merupakan tinggi gelombang pecah, $d_{b}=2 \mathrm{~m}$ merupakan kedalaman gelombang pecah, $a_{b}=8^{\circ}$ merupakan sudut datang gelombang pecah dan $w=21$ adalah groin berada pada titik $x=21$. Data $C_{n}, H_{b}, d_{b}, a_{b}$, dan $w=21$ diambil dari data Triatmodjo (1999) untuk membandingkan dengan solusi numerik yang telah dihasilkan.

Gambar (1)(a) adalah grafik perubahan garis pantai dengan menggunakan metode numerik pada (Triatmodjo, 1999), sedangkan Gambar (1)(b) adalah grafik perubahan garis pantai dengan metode analitik transformasi Elzaki. Berdasarkan Gambar (1) dapat dilihat bahwa terdapat kesamaan antara pola grafik yang dihasilkan dari solusi model perubahan garis pantai yang telah dihasilkan secara analitik dan numerik yaitu sebelah hulu groin mengalami akresi sedangkan sebelah hilir groin mengalami abrasi. Hal ini terjadi karena groin akan menahan gerak sedimen di sebelah hulu sementara transpor sedimen di sebelah hilir masih tetap terjadi namun suplai dari sebelah hulu terhalang oleh groin.

\section{Simulasi di Sebelah Hulu Groin}

Dalam simulasi ini diasumsikan groin berada pada titik $x=21, D=0,57 \mathrm{~mm}$, $\rho=1030 \frac{\mathrm{kg}}{\mathrm{m}^{2}}, \quad \rho_{s}=2650 \frac{\mathrm{kg}}{\mathrm{m}^{2}}, g=9,8 \times(24 \times 3600)^{2} \mathrm{~m} /$ hari $^{2}, \quad n=0,4, \quad C_{n}=5 \%, \quad H_{b}=$ $1,5 m, d_{b}=2 m, a_{b}=8^{\circ}, x=0-4000 m, t=30$ hari. pada Gambar (2)(b), (c), (d), (e), (f), dan (g) nilai yang disimulasikan berubah masing-masing menjadi $t=50$ hari, $D=0,7 \mathrm{~mm}$, $H_{b}=1, m, d_{b}=1 m, a_{b}=5^{\circ}$, dan $a_{b}=-8^{\circ}$. Hal ini bertujuan untuk melihat pengaruh waktu $(t)$, ukuran butiran sedimen pantai $(D)$, tinggi gelombang pecah $\left(H_{b}\right)$, kedalaman gelombang pecah $\left(d_{b}\right)$ dan sudut gelombang pecah $\left(a_{b}\right)$ terhadap perubahan garis pantai yang terjadi.

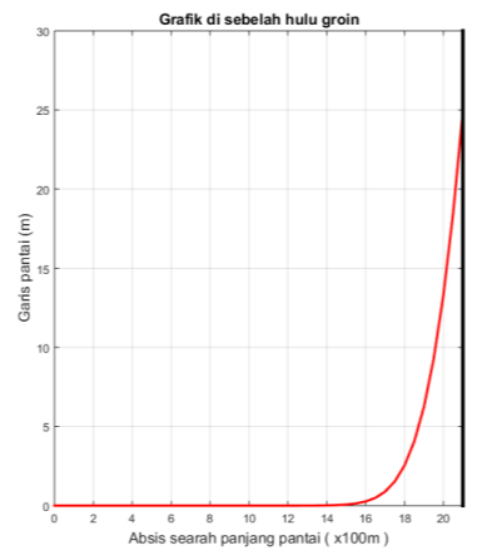

(a)

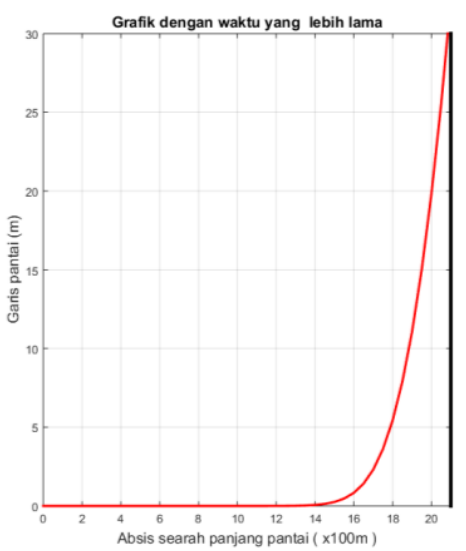

(b)

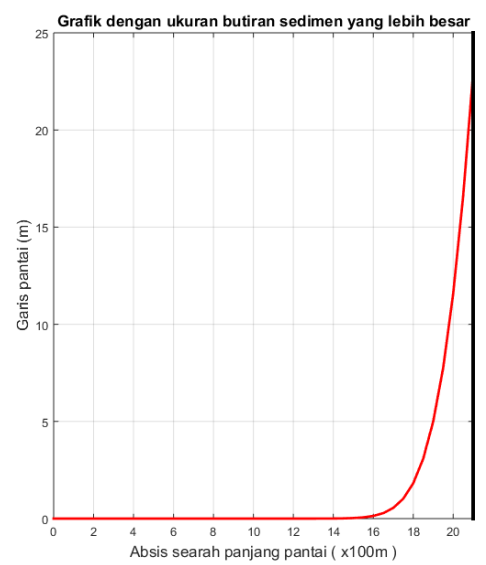

(c) 


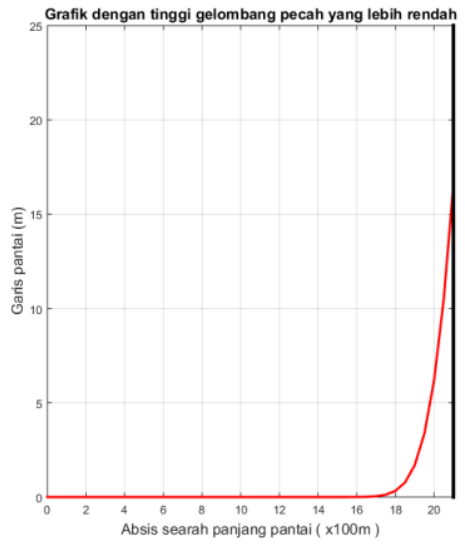

(d)

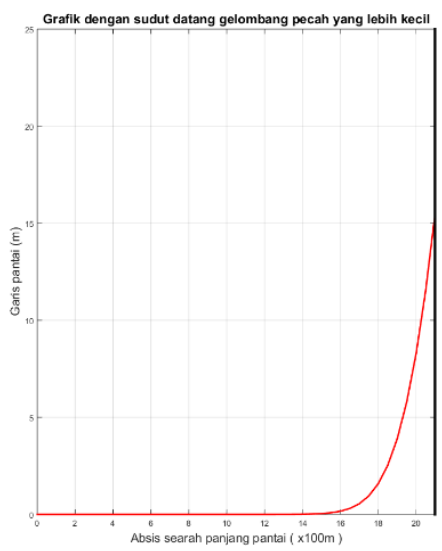

(f)

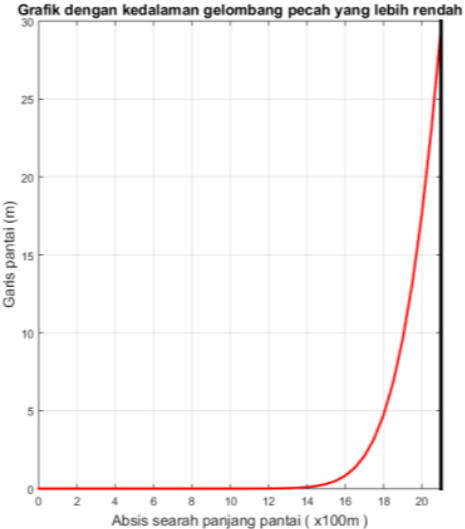

(e)

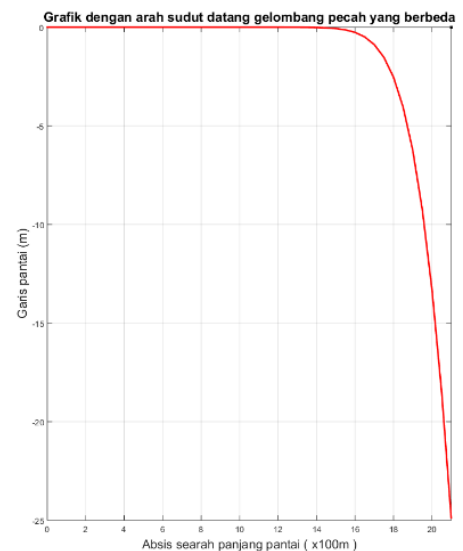

(g)

GAMBAR 2. Simulasi disebelah hulu groin

Berdasarkan simulasi, diperoleh bahwa besarnya $H_{b}$ dan $a_{b}$ sebanding dengan besarnya perubahan garis pantai yang ditimbulkan sedangkan besarnya $D$ dan $d_{b}$ berbanding terbalik dengan besarnya perubahan garis pantai. Serta arah datang dari gelombang pecah mempengaruhi suatu pantai akan mengalami abrasi atau akresi.

\section{KESIMPULAN}

1. Solusi model perubahan garis pantai adalah:

$$
y(x, t)=\left\{\begin{array}{l}
\sqrt{\frac{2 Q_{0}}{d}} \tan \left(a_{b}\right)\left(2 \sqrt{\frac{t}{\pi}} e^{-\frac{d}{8 Q_{0} t}(w-x)^{2}}-\sqrt{\frac{d}{2 Q_{0}}}(w-x) \operatorname{erfc}\left(\frac{\sqrt{\frac{d}{2 Q_{0} t}}(w-x)}{2}\right)\right),-\infty<x \leq w \\
-\sqrt{\frac{2 Q_{0}}{d}} \tan \left(a_{b}\right)\left(2 \sqrt{\frac{t}{\pi}} e^{-\frac{d}{8 Q_{0} t}(x-w)^{2}}-\sqrt{\frac{d}{2 Q_{0}}}(x-w) \operatorname{erfc}\left(\frac{\sqrt{\frac{d}{2 Q_{0}}}(x-w)}{2}\right)\right), w \leq x<\infty
\end{array}\right.
$$

2. Terdapat kesamaan antara pola grafik yang dihasilkan dari solusi model perubahan garis pantai dengan metode transformasi Elzaki dan metode numerik, yaitu sebelah hulu mengalami akresi dan sebelah hilir mengalami abrasi. 
3. Berdasarkan hasil simulasi, diperoleh bahwa yang mempengaruhi perubahan garis pantai adalah ukuran butiran sedimen pantai $(D)$, tinggi gelombang pecah $\left(H_{b}\right)$, kedalaman gelombang pecah $\left(d_{b}\right)$ dan sudut gelombang pecah $\left(a_{b}\right)$. Besarnya $H_{b}$ dan $a_{b}$ sebanding dengan besarnya perubahan garis pantai yang ditimbulkan sedangkan besarnya $D$ dan $d_{b}$ berbanding terbalik dengan besarnya perubahan garis pantai. Serta arah datang dari gelombang pecah mempengaruhi suatu pantai akan mengalami abrasi atau akresi.

\section{DAFTAR PUSTAKA}

Dabees, M. A. (2000). Efficient Modelling of Beach Evolution. Ontario: Queen's University Kingston.

Elzaki, M. T. (2011). The New Integral Transform "ELzaki Transform". Global Journal of Pure and Applied Mathematics, 7(1), 57-64.

Elzaki, M. T., Elzaki, M. S., \& Elnour, A. E. (2012). On some Applications of New Integral Transform "Elzaki Transform". Global Journal of Mathematical Sciences: Theory and Practical International Research Publication House, 4(1).15-23.

Minarti, N., Kiftiah, M., \& Helmi. (2015). Penyelesaian Persamaan Diferensial Parsial Linear Dengan Menggunakan Metode Transformasi Elzaki. Buletin Ilmiah Mat. Stat. dan Terapannya (Bimaster), 04(3). 227 - 236.

Sakka. (2011). Studi Perubahan Garis Pantai di Delta Sungai Jeneberang. Jurnal Ilmu dan Teknologi Kelautan Tropis, 3(2). 112-126.

Side, S. (2014). Persamaan Diferensial Parsial. Makasaar: Universitas Negeri Makassar.

Triatmodjo, B. (1999). Teknik Pantai. Yogyakarta: Beta Offset.

USACE, (. S. (2003). Coastal Sediment Processes, Part III. Washington DC: Department of the Army. U.S. Army Corp of Engineers.

Yuni, S. M., Setiawan, I., \& Maufiza, O. (2014). Solusi Analitik Model Perubahan Garis Pantai Menggunakan Transformasi Laplace. Jurnal Gradien, 10(2). 1005-1013. 